\title{
ENGLISH TRANSLATIONS AND TRANSLITERATIONS
}

Quotations of lemmas from the "Short Enumeration" are from Moses Hyamson's translation of the Mishneh Torah. Quotations from the Sefer ha-Mitsvot are from C. D. Chavel's translation (The Book of Commandments). Quotations from The Guide of the Perplexed are from Shlomo Pines' translation, cited by book, chapter, and page (in italics). Quotations from the Shemonah Peraqim are from Weiss and Butterworth's English translation. I have followed all of these translations quite faithfully; in the rare places where I amend any of them, I note my change. In contrast, the English quotations from the Mishneh Torah are my own adaptations of the Yale University translation (multiple editors).

For scriptural quotations, I used J. H. Hertz's translation of the Pentateuch to match Chavel's use of biblical passages in his own translation of the Sefer ha-Mitsvot. There will be instances, however, when exegetical derivations will not quite conform to these scriptural translations. Any inconsistencies are likely a result of the nuanced and ambiguous language of Scripture. I did my best to adapt these translations so that the reader will follow the interpretation.

By Sages (with a capital "S"), I refer to the authorities of the talmudic period.

The proliferation of transliteration systems found in scholarly works is nothing short of bewildering. Preferences are often a function of the scholar's academic and geographical background. For example, a student from the Lithuanian yeshiva tradition would differentiate the $\operatorname{tav}(t)$ from the spirant variety $(t h)$. An Israeli student, accustomed to the modern Sephardic pronunciation, would not. The field of Biblical 
Studies, because of its emphasis on grammatical and morphological features, has tended to use the scientific or academic system. This work, however, is less concerned with the morphology of biblical passages as it is with idioms of the interpreters, the Sages, and medieval rabbis. With the exception of commonly used spellings, I have therefore adopted what I considered the simplest transliteration system, the "generalpurpose style" of the Society of Biblical Literature Handbook of Style, with some slight modifications (ignoring the spirants $g h, d h$, $f h$, and th in favor of $g, d, f$, and $t$ ). I retain original Hebrew words or sentence where the translation may leave doubts as to the precise intention of the original rabbinic text.

Throughout the work, I make a clear distinction between the terms Mishneh Torah and Halakhot (of the Mishneh Torah). The full work of the Mishneh Torah consists of treatises, divided into Introductions, Headings, and Halakhot. I use the term Mishneh Torah to refer to this full work. When referring only to the text of the Halakhot themselves, without their Headings, I use the term Halakhot. I capitalize the term "Headings" because I treat them as a separate work, likely composed at a different time from the Halakhot. While the Headings likely derive from the "Short Enumeration" and the Sefer ha-Mitsvot, they contain many important differences in formulation, which have legal and exegetical implications. 